\title{
Özel Diplomatik Analiz Metodu: Sağlık Bakanlığında Üretilen İki Yazışma Üzerinde Uygulama
}

\author{
Special Diplomatics Analysis Method: The Application in \\ Correspondence of the Ministry of Health
}

\section{Niyazi ÇiçEK}

\section{Öz}

Belgelerin güvenilirliğinin değerlendirildiği bir uygulama olan diplomatik analiz, her ne kadar güncelliğini yitirmiş malzeme üzerinde yürütülen bir metot olsa da, günümüz belgeleri için de kullanılabilmektedir. Bu yüzden Osmanlı belgeleri gibi Cumhuriyet dönemi belgelerinin de diplomatik analizi yapılabilir. Çalışmalar, güncel evrakın, hatta elektronik dokümanların dahi diplomatik açıdan incelenebileceğini göstermektedir. Bu makalede özel diplomatik analiz prensipleri ele alınmış, Sağlık Bakanlığı tarafından üretilmiş olan iki yazışma üzerinde uygulama yapılmıştır.

Anahtar sözcükler: Arşivcilik - Diplomatik, Diplomatik analiz, Diplomatik Belgeler.

\begin{abstract}
Diplomatic analysis, which comprises the study on the authenticity of rather inactive records like those of the Ottomans, can also be applied to recent records, and among them the electronic type of records. The study aims at the discussion of principles of special diplomatic analysis, and an exemplification is brought by through a sample application out of the correspondence of Ministry of Health.
\end{abstract}

Keywords: Archives - Diplomatics, Diplomatic Analysis; Diplomatics Records.

\section{Giriş}

Diplomatiğin, ilk olarak 1681'de tarih bilimine yardımcı olmak amacıyla Fransız Dom Jean Mabillion tarafından kullanıldığı bilinmektedir. Mabillion, belgelerin güvenilirliğinin incelenebilmesi için diplomatik bir metot geliştirmiştir. Daha sonra yapılan çalışmalar, bu metodun bir disiplin haline gelmesini sağlamıştır. Önceleri tarih araştırmalarına kaynaklık eden dokümantasyonun değerlendirildiği bu disiplin, hukuk başta olmak üzere

*Dr.; Marmara Üniversitesi Fen Edebiyat Fakültesi Bilgi Belge Yönetimi Bölümü, İstanbul (ncicek@marmara.edu.tr). 
arşivciliğe de yardımcı olmaktadır. Diplomatik, genellikle güncelliğini kaybedip arşiv malzemesi olmuş belgeler üzerinde uygulanmaktadır. Son dönemde yayımlanan çalışmalarda, bu yüzyıla ait günümüz belgeleri ile henüz arşivlik malzeme olmamış güncel belgelerin incelenmesinde de kullanılabileceği anlaşılmaktadır.

Tarih, hukuk ve arşivcilik gibi farklı alanlarda kullanılan diplomatik birçok uzmanın ilgisini çekmiştir. Bu konu üzerine yaptığı araştırmalarla ön plana çıkan akademisyenlerden birisi de İngiliz Kolombiya Üniversitesinde (The University of British Columbia) arşivcilik ve diplomatik dersleri veren Luciana Duranti'dir. Duranti, (1989, 1989-1990, 1990 1990-1991 1991, 1991-1992), 1989-1992 yılları arasında Archivaria'da bir seri olarak yayımladığı "Diplomatik: Eski Bilimin Yeni Kullanımı" adlı altı makalesinde, diplomatik metotların bu yüz yıl içerisinde üretilen daha çok günümüze ait belgeler üzerinde kullanılmasını incelemiştir. Önemli bir kaynak niteliği taşıyan bu seri, bu konuya ilgi duyan birçok arşivci ve uzman tarafından kullanılmış, yeni çalışmalara referans olmuş ve daha sonra kitap olarak yayımlanmıştır (Duranti, 1998). Bu yazının teorik alt yapısını oluştururken Duranti'nin bu çalışmalarından büyük ölçüde yararlanılmıştır. Duranti'nin dışında günümüz belgelerinin diplomatik analizini ele alan farklı yayınlara rastlamaktayız (Skemer, 1989; Storch, 1998). Hatta elektronik belgelerin diplomatiğiyle ilgili projelerin yürütüldüğü bilinmektedir (InterPRASE Project, 2005).

Türkiye'de ise Osmanlı belgelerinin paleografya ve diplomatiği hakkında yapılmış çalışmalar bulunmasına rağmen Cumhuriyet dönemi belgeleri incelenmeyi beklemektedir. Bu döneme ait belgelerin diplomatik özelliklerini ortaya koyacak esaslar bulunmamaktadır. Yazışma kurallarıyla ilgili yönetmelik ve standartlar, aynı zamanda dosyalama, yazışma ve kurum kodları gibi farklı dokümanlar, her ne kadar belgeleri şekil olarak değerlendirme olanağı sağlasa da, tek başlarına diplomatik açıdan entelektüel analiz yapma imkânını yeterli düzeyde vermemektedir. Ancak, belgelerin form özellikleri bu prosedürlerde geçen kurallara göre şekillendiğinden, iyi bir diplomatik analiz yapabilmek için bu kuralların referans alınması gerekir. Bu kurallar ve önceden belirlenmiş idari usul çerçevesinde resmi nitelik kazanan belgelerin güvenilir olup olmadıklarının nasıl belirleneceği, cevaplanmayı bekleyen bir soru olarak karşımızda durmaktadır. Bulunacak cevap, arşiv uygulamaları başta olmak üzere, tarih ve hukuk gibi bilim dallarında belgelerin güvenilirliğiyle ilgili çıkabilecek problemlerin çözümüne yardımcı olacaktır.

Görülen bu eksikliğin giderilmesine bir katkı sağlamak için bu makalede güncel belgelerin diplomatiği konusu incelenmiştir. Makalenin amacı, genellikle arşivlik belgelerde denenen diplomatik analiz yönteminin, Ogüncel belgeler üzerinde de uygulanabileceğini göstermektir. Cumhuriyet dönemine ait belge türleri bir makaleye sığamayacak kadar çok olduğundan, bu çalışma 
güncel iki belge ile sınırlandırılmıştır. Yazışma türü içerisinde bir "makam oluru" ve onun "üst yazısı" olan bu belgeler, İstanbul ilı Sağlık Müdürlügünde yapılan saha çalışması sırasında örnekleme yoluyla belirlenmiştir (İstanbul ì Sağlık Müdürlügü [iSM], 1999). Seçilen belgelerin diplomatik özellikleri incelenmiş, idari ve bürokratik işlemleri açıklanmış, fonksiyonla ilişkisi değerlendirilmiştir. Burada kullanılan diplomatik analiz yöntemi, şartname, sözleşme, kontrat, kurul kararı, toplantı tutanağı vb. daha birçok belge türüne genellenebilir. Bu analiz çalışması yapıırken, diplomatik bilimi içerisinde belgelerin içerik ve türüne göre form özelliklerini inceleyen "özel diplomatik" alanıyla ilgili veriler kullanılmışıı (Bkz. Tablo 1 ve Tablo 2). Bu makalede öncelikle diplomatiğin teorik çatısı üzerinde durulmuş, ardından yöntemde uygulanacak başlıca veri alanları ele alınmış, son olarak bu alanlar çerçevesinde yürütülen uygulamayla güncel belgelerin diplomatik analizinin nasıl yapılacağı gösterilmeye çalışılmıştır.

\section{Diplomatik}

Belge bilimi anlamına gelen diplomatik, belgelerin orijinal veya sahte olup olmadığını, türünü, üretildiği kaynak ve dönemini, idari ve bürokratik durumunu belirlemek için kullanılır (Duranti, 1989, s. 15). Diplomatik, belgelerin incelenebilmesi için yöntem belirlemiştir. Bu yöntem, belgelerin form özellikleriyle beraber üretim prosedürlerini, üreten kaynakları, kurumun idari ve teşkilat yapısını aynı zamanda belgenin üretildiği fonksiyonu kapsamaktadır. Diplomatik analiz yöntemi, belirsizlikleri bulunan ve anlaşılmaya çalışılan bir belge hakkında bilgi verir. Onun özel diplomatik bilgilerini tahlil ederek, güvenilirliği hakkında kesin tespitler yapmayı sağlar. Hatta bu bilgiler, iyi bir analizle, dokümanın oldukça önemsiz gibi gözüken küçük parçaları üzerinde düşünmekle de elde edilebilir (Turner, 1990, s. 99). Bu diplomatik bilgiler, belgenin öncesi hakkında değerlendirme yapmaya imkân verdiği gibi dokümanın anlaşılmayan yönleriyle ilgili ipuçları sunar. Böylece bir belgenin tanımlanabilmesi için gerekli olan bilgiler, diplomatik analiz sonucunda onun form yapısından çıkarılarak elde edilecek ayrıntılarla desteklenip pekiştirilebilir. Bu durum, arşivciye yapacağı niteleme ve düzenleme çalışmasında daha entelektüel davranma olanağı sağlayacağı gibi bilgi kullanıcılarına da malzemeyle ilgili doyurucu ve ayrıntılı bilgi bulma fırsatı verir.

\section{Genel ve Özel Diplomatik}

Diplomatik, her ne kadar belgelerin orijinalliğinin belirlenmesiyle ilgili bir çalışma olsa da, özellikle arşiv uygulamalarında provenans anlayışına paralel olarak, belgelerin ait olduğu kurumsal ilişkiyi ortaya çıkarmak için de kullanılmaktadır. Be sebeple uzmanlar diplomatiği arşivcilik bakımından değerlendirirken, "genel diplomatik" ve "özel diplomatik" olmak üzere iki 
şekilde ele almaktadırlar (Duranti 1989, s. 16). Genel diplomatik anlayışında, belgelerin üretim süreci incelenerek, fonksiyonu, ait olduğu serisi ve dosyası analiz edilmektedir. Özel diplomatikte ise diplomatik kuralların analizi ve formülleştirilmesiyle ortaya konan genel dokümantasyon bilgisinden daha çok, tek ve kolay örneklendirilebilen belgelerin form özelliklerini inceleyen teorik prensipler üzerinde durulur (Duranti, 1989, s. 16). Böylelikle özel diplomatiği, genel diplomatiğin bir parçası olarak kabul etmek mümkündür.

\section{Genel Diplomatik}

Tek belgeden daha çok dosya ve seriyi kapsar. Bir belgenin form özellikleri yerine onun kaynağı, bulunduğu dosya ve serisi üzerinde diplomatik analiz yapılır. Böylece genel diplomatik, belgelerin bulunduğu dosyanın taşıdığı genel özellikleri, temsil ettiği faaliyeti ve üreten kaynaklarla ilişkisini içermek üzere oluşturulan teorik bir çatı şeklinde ortaya çıkmaktadır (Storch, 1998, s. 366).

Genel diplomatik kuralları içeren bu çatı, özellikle bir serinin nasıl ve niçin üretildiğinin belirlenmesinde arşivcilere yardımcı olur. Bu durumda genel diplomatiğin, bir belgenin üreticisi, üretim prosedürleri, arşive devri, bulunduğu dosya ve seri sürecinde belgenin organik bağlantısını incelemek için oluşturulduğunu söylemek mümkündür. Bundan dolayı genel diplomatik incelemesi, öncelikle belgelerin kamu kurumlarına mı yoksa özel işletmelere mi ait olduğu işleminden başlayarak, bulunduğu koleksiyon ve düzenleme işiyle devam etmektedir.

Belgelerin niçin ve ne maksatla bir seride bulunduğunun belirlenmesi, doğru tanımlanmaları açısından önemlidir. Bulunacak cevaplar, hem dosya profilinin hem de dosyaların bulunduğu serinin değerlendirilmesinde kullanışlı araçlar sunar. Bir dosyanın üretildiği kaynak tespit edilip birim ve fonksiyon ortaya çıkarılamıyorsa, dosya ile fonksiyon arasındaki bağ da kurulamıyor demektir. Bu olumsuz durum, hiç şüphesiz tanımlama yaparken entelektüel davranmayı engeller. Bir dosya serisi organizasyon içerisindeki bir birimin fonksiyonu kapsamında oluştuğundan, belgede olduğu gibi dosya ve seride de o birime ait tanımlanabilir ipuçları bulunabilir. Çünkü dosya ve seri fonksiyonla doğrudan ilişkilidir. Genel diplomatik çalışmalar bu ilişkiyi kurmaya yardımcı olur. Başka bir deyişle, bir dosyanın üretildiği süreç içerisinde temel adımları oluşturan iş, fonksiyon, seri ve dosyanın sadece tespitinin yapılması iyi bir tanımlama için yeterli değildir. Genel diplomatik analiz metodu kullanılarak bu unsurlar arasındaki bağın çok iyi kurulması gerekir.

Bir dosyanın sadece kimler tarafından ve nerede üretildiğini bilmek, onun nitelemesini yapabilmek için doyurucu bir bilgi sunmamaktadır; aynı zamanda bu üreticilerin organizasyon hiyerarşisindeki yerinin nere olduğu bilinmelidir. Çünkü arşivciler, dosyaları düzenlerken onları üretenlerin organizasyon 
içerisindeki konumlarını göz önünde bulundururlar (Storch, 1998, s. 366). İşte bu hiyerarşik yapının ortaya çıkarılmasına büyük katkısı olan genel diplomatik, belgelerin üretildiği kaynağa ait kurumsal ilişkinin belirlenmesinde provenans uygulaması kadar kullanışlı bir araçtır.

Görüldüğü gibi genel diplomatik daha çok arşiv uygulamalarında belgeyle birlikte dosya ve seriyi kimin, nerede ve hangi amaç için ürettiği sorularına cevap bulmaya yardımcı olur.

\section{Özel Diplomatik}

Genel diplomatiğin temel prensiplerini kabul edip değerlendirmekle beraber, esas olarak tek bir belgenin form unsurlarıyla ilgilenir ve özelliklerini analiz eder (Storch, 1998, s. 367). Bundan dolayı özel diplomatiğin konusunun doğrudan belge formu olduğunu söylemek mümkündür.

Belgeler belirli bir idari usul ışığında işlem görerek ortaya çıkar. Bu durum, aslında iletilmek istenen mesajın, verilmek istenen bilginin sunum kuralları çerçevesinde kayda geçirilip aktarılmasıdır. Dolayısıyla yazışma kuralları ve üretilmesine sebep olan mevzuat çerçevesinde her belge geçirdiği idari işlemlerle bir takım form unsurlarına sahip olur. Bu durum, aynı zamanda türüne göre belgede bulunan karakteristik yapıdır.

Bir belgenin karakteristik yapısını teşkil eden form özelliklerini ise bir takım sunum kuralları biçimlendirir. Belge formuna şekil veren bu kurallar, en başta alfabe gibi bilinen anlaşıı iletişim sembolleri, dil bilgisi, kayıt ortamı, fonksiyon, idari usul ve işlemler biçimindeki farklı faktörlerdir. İşte bu kuralların işletilmesiyle belge, ait olduğu türe göre bir karakteristik yapıya sahip olarak doğar. Böylece belirtilen bu kurallar kümesi bir belgenin kendi içyapısını oluşturmasını sağlar. Aynı zamanda, içeriğe ait politik, hukuki, idari, kültür, alışkanlıklar ve ekonomik yapıyı da etkiler. Bir belgenin form özellikleri tüm bu elemanların birbiriyle olan ilişkilerini gösterir (Storch, 1998, s. 367).

Özel diplomatiğin gerektirdiği form analizi oldukça ayrıntııdır. Bu analiz, bir şekilde incelenen doküman tarafından yönlendirilir. Bu sebeple belge formunu, onu oluşturan parçaların çokluğuna ve üretildiği kaynak olan idari tarih zenginliğine göre farklı ayrıntı düzeylerinde analiz etmek mümkündür. Fakat bu şekilde oldukça titiz ve ayrıntılı bir inceleme, arşivciler için tavsiye edilen bir yol değildir (Storch, 1998: 367). Çünkü dosya düzeyinde bir nitelemenin yapıldığı arşivde, özellikle belge düzeyinde diplomatik analiz yapmaya kalkmak, takdir edileceği gibi zaman alıcı bir çalışma olacaktır. Binlerce hatta milyonlarca belgenin bu şekilde bir diplomatik analizi, pek de olası bir uygulama olmasa gerek. Bunun yerine, diplomatik metotlar belge türleri düzeyinde uygulanabilir. Bu durum arşivci ve arşiv için daha yerinde bir çalışma gibi gözükmektedir. 


\section{Belge Formunu Oluşturan Unsurlar}

Kurumlarda yürütülen bir fonksiyon kapsamında doğal olarak üretilen bir belge, antet, sayı, imza, mühür gibi birçok unsurdan oluşur. Bu unsurlara, "belgelerin üretildikleri fonksiyonla form özelliklerinin ilişkisini" ele alan (Çiçek 2004: 139-148) yazıda kısaca değinilmişti. Ancak, diplomatik yönden inceIenmemişlerdi. Bir belgenin karakteristik yapısını oluşturan bu unsurlar, diplomatik metodu doğrudan ilgilendirdiğinden, burada ayrıntılı olarak değerlendirilecektir.

$\mathrm{Bu}$ unsurların bir kısmı, belgenin içerik yapısıyla ilgili olup onun bilgi yönünü, diğer bir kısmı ise daha çok şekil yönünü niteler. Böylece belgelerin hem fiziksel hem de entelektüel olmak üzere iki temel boyutunun olduğunu söylemek mümkündür. Bu durumda taşıyıcı ortam ister kâğıt, isterse elektronik evrak olsun kaynaklara göre belgelerin bu biçimsel tarafını şekillendiren araçlar dış kaynaklardan gelen unsurlar iken, entelektüel boyutunu inşa eden iç etkenlerdir. Duranti, bu unsurları "iç kaynaklı elemanlar" (extrinsic elements) ve "dış kaynaklı elemanlar" (intrinsic elements) şeklinde kullanmıştır (1991, s. 6). Ayrıca, dış kaynaklı olan elemanlara belgenin fiziksel formu, iç kaynaklı olanlara ise entelektüel formu denildiğini görüyoruz (Storch, 1998, s. 367).

\section{Iç Kaynaklı Elemanlar}

Bir yazı idari işlemler sırasında tarih, adres, metin, kayıt ve onay bilgileri gibi çeşitli form elemanlarına sahip olarak doğar. Belgenin temel bilgi alanları olan bu elemanlar, hukuk, idari usul, işlem ve gelenekler yanı sıra yazım kurallarıyla biçim alır. Bundan dolayı iç kaynaklı elemanlar, belgenin entelektüel analizinde temel bileşenleri teşkil eder.

Dokümanları entelektüel olarak inceleyen konu uzmanları, bu elemanları belirli gruplar altında değerlendirmişlerdir (Duranti, 1991, s. 11). Belgenin analitik biçimde bölünmesi anlamına da gelen bu gruplamanın ilk öğesi "protokol"dür: Belgenin idari açıdan kurumsal ve fonksiyonel ilişkisini belirtir. İkincisi "metin"dir ve belgenin doğuşuna sebep olan konuyu açıklar. "Tasdik" alanı olarak adlandırılan üçüncü kısım ise belgenin idari sorumlusunu gösterir.

Protokol: Bu alanda bir belgenin üreteni ve üretimiyle alâkalı idari prosedürler ortaya konulur (Duranti, 1991, s. 11). Protokol belgenin üretildiği zamanı, yeri, üreten tüzel kişiliği, başlığı, adresi ve ilgili referansları kapsar. Belgenin kimlik bilgilerinin verildiği bu yer, belge türüne göre bir takım farklılıklara sahip olsa da, özellikle yazışmalarda belirli bir standarda kavuşmuştur. 
Protokol alanında ilk göze çarpan eleman genellikle antettir. Kamu idaresinde üretilen yazışmalarla ilgili olarak çıkarılan "Resmi Yazışmalarda Uygulanacak Esas ve Usuller Hakkında Yönetmelik”te (T.C. Başbakanlık, 2005) birçok temel eleman gibi antedin de muhafaza edildiği görülmektedir. Antet, belgeyi üreten kişinin veya kurumun adresi, ismi, mevki ve sıfatını ifade eder. Bundan dolayı bir belge diplomatik açıdan ele alınıp güvenilirliği tespit edilirken, çıktığı kaynağın öğrenilip sorumlu kurumun belirlenmesinde ilk değerlendirilecek yerin antet olduğu görülür.

Bir belge ister kamu idaresinde üretilsin, isterse özel bir işletmeden çıksın tarih bilgisi vazgeçilmez bir elemandır. Yazışmalara genellikle tek bir tarih verilirken özellikle "makam oluru" gibi yazılarda yetkili belgeyi imzalarken o günün tarihini belirttiğinden, bir belgede birden fazla tarih bilgisi bulunabilir. Her ne kadar yazının hazırlanma tarihi ile onayı verecek olan amirin imza zamanının aynı gün olmasına çalışılsa da, farklı onay makamlarının bulunması sebebiyle belgeyi hepsinin aynı gün imzalaması söz konusu olmadığında, tek bir tarih yerine yazıda birkaç farklı tarih görmek mümkündür. Bu durum idari ve diplomatik açıdan belgenin güvenilirliğine ve orijinalliğine herhangi bir zarar vermez. Ayrıca, dış kaynaklı bir eleman olarak değerlendirilse de, belgeler kurumlarda ilgili birime havale edilirken düşülen şerhlerle beraber tarih bilgisi de verilmektedir. Aynı şekilde, kayıt işlemleri sırasında evrakların kuruma giriş tarihi yazılmaktadır.

Belgelerde bulunan sayı ve konu alanı, iç kaynaklı elemanlardandır. Örnek belgelerde sol üst tarafta 'Sayı: B100DIŞ0000007 / 6617' biçiminde yer alan bilgi alanında, belgeyi üreten kurumun devlet içerisinde yasama "A", yürütme "B" ve yargı " $\mathrm{C}$ " gibi hangi erke ait olduğunu gösteren harfinden sonra başlıca kurum, birim ve alt birim bilgilerini işaret eden rakam ve harfler, ardından hizmet türü veya dosya kodu son olarak evrak kayıt numarası bulunmaktadır (Bkz. Ek 1 - Ek 2). Sayı kısmı, her ne kadar iç kaynaklı olsa da özellikle evrak kayıt ve dosya tasnif numarası, belgeye sonradan dâhil olduğundan dış kaynakıı eleman olarak değerlendirilebilir. Ancak, belgenin entelektüel analizinde oldukça kullanışlı veriler sunduğundan iç kaynaklı kabul etmek daha tutarlı bir yaklaşım gibi gözükmektedir.

Belgenin bir adrese sahip olması önemli bir form özelliğidir. Çünkü bir belgenin kimin için hazırlandığı ya da kime ve hangi kuruma gönderileceğinin belirli olması gerekir. Belgenin iletimi için bu alan oldukça anlamlıdır; aynı zamanda dokümanı oluşturan parçalar arasında vazgeçilmez bir elemandır. Kamu yönetiminde "gönderilen makam" (T.C. Başbakanlık, 2005) denilen bu kısımda yazının gideceği adres belirtilir. Örneğin üzerinde diplomatik analizin yapıldığı ekte verilen örneklerde geçen "iSTANBUL VALiLiĞi (il Sağlık Müdürlüğü)" (Bkz. Ek 1) ve "BAKANLIK MAKAMINA" (Bkz. Ek 2) biçimindeki form elemanları, adres bilgi alanını teşkil etmektedir. Özel kurum ve şahıslarla 
yapılan yazışmalarda yazının muhatabı olan tarafa hitap edildiği için bu kısma "hitap başlığı" denildiği de görülür (Kandur, 2002, s. 56). Bütün yazışmalarda yazıyı düzenleyen tarafın tüzel kişiliğini ifade eden bir ad ve unvanın yer aldığı bir antet bulunmayabilir. Bu tür örneklerle karşılaşılması durumunda Storck (1998, s. 371), adres alanının başlık olarak değerlendirilmesi gerektiğini belirtilmektedir.

Antet ve adres alanlarından ayrı olarak özellikle yazışma türü belgelerin dışındaki sözleşme, şartname, kontrat, rapor ve yönetmelik gibi daha birçok belgenin sahip olduğu "Beykoz Çevresinin Jeoloji ve Jeofizik Açısından Yerleşime Uygunluk Değerlendirmesi Raporu", "Marmara Üniversitesi 1998/187-189 Yılı Senato Kararları" biçimindeki belge başlıkları da bir iç kaynaklı eleman olarak kabul edilmektedir. Bu eleman, belgenin konu başlığını oluşturur; içeriğini açıkladığı gibi sahip olduğu ayrıntıya göre kaynağını, tarihini, sayısını ve fonksiyonunu yansıtır. Böylece belgeyi, bu fonksiyon altında tasnif yaparak, diğer dokümanlardan ayırma imkânı verir.

Metin: Belgelerde protokolün ardından metin alanı gelir. Metin bir dokümanın esas bölümüdür. Yazı sahibinin ya da sorumlu makamın düşünceleri, yapılmak istenen eylem, onun delilleri, açıklamalar ve ana tema bu kısımda belirtilir. Başka bir deyişle, yazarın demek istediği, bildirdiği, vakayı ve düşüncelerini aktardığı yerdir (Storch, 1998, s. 372). Belgenin varlık nedeni, tarihi, idari ve hukuki gerekçeleriyle açıklanıp, ortaya konduğu için en önemli iç kaynak elemandır. İncelenen belge türlerinin analizinde, bir dokümanın metin alanının giriş, esas konu ve sonuç kısmından meydana gelir. Dolayısıyla bu alan, başlangıç, takdim, konuyu haber verme, açıklama, tartışma ve değerlendirmeler ile son cümleleri kapsar. Bu bilgilerin ortaya konuluş biçimi belge türüne göre farklılık gösterebilir. Ancak, düşüncelerin düzenli ve planlı aktarımı her belge türü için önemli bir noktadır.

Sorumluluk: Belge türüne göre "saygılarımla" biçiminde muhataba duyulan saygıyı gösteren iltifat sözcük veya cümleleri ile belge sorumlusunun onay ve tasdiki, bu alanda yer alır. Sorumluluk, belge sahibinin imza formu ve mühür gibi işaretlerle ortaya konur (Duranti, 1991, s.14).

Yazılı iletişim yapılırken, kamu idaresi başta olmak üzere özel işletmelerin yönetiminde de ast üst ilişkilerine dikkat edilmektedir. Bundan dolayı metin içerisinde kullanılan terimlere ve üsluba özen gösterilirken, özellikle bitiş cümleleri ve saygı ifadelerindeki kelimeler dikkatlice seçilir. Özel şahıslara gönderilen mektuplar başta olmak üzere, yazışmalarda "saygılarımla" veya "saygılarımızla" gibi iltifat sözcükleri sıklıkla kullanılan ifadelerdir.

Bu şekilde verilen bitiş ve saygı ifadelerinin ardından gelen tasdik alanı, bir belgenin diplomatik analizinde oldukça anlamlıdır. İmza, bir belgenin resmi olarak geçerliliğini gösteren ilk elemanlardan biri olduğundan, herhangi bir yazının belge gibi işlem görebilmesi için, belge formunda mutlaka 
bulunmalıdır. Belgeye son şeklinin verilmesinin ardından idari sorumluluğu taşıyan kişi/kişilerin imzaları ve isimleri, metnin bitiminin ardından son kısımda gösterilir. Sorumluluk alanında, işin ve dokümanın sorumlusu, yazan, ikinci imza yetkilisi gibi farklı idari makamlara ait isim, unvan ve imzalar olabilir. Ayrıca, imza sahipleri bu hakkı, vekâleten veya verilen yetki ile esas amirin adına kullanabilir. Kamu idaresindeki yazışmalarda bu tip uygulamalar şu şekildedir: Eğer imza sahibi bir yetki kullanarak evrakı imzalıyorsa, yetkili makam unvanının yanına "adına" anlamına gelen "a." şeklinde, asaleten değil de vekâleten o makamda bulunuyorsa vekil anlamına gelen "V." harfleri kullanılarak gösterilir (T.C. Başbakanlık, 2005). Bu uygulamaların dışında bazı kurumlarda, eğer imza, adı yazılı olan kişiye ait değil de onun yerine bir başkasına ait ise adın sonuna imza atılan kalemle yerine anlamına gelen "Y" harfinin yazıldığı görülmektedir (Öztek, 1999, s. 68). İşte diplomatik, dokümanın provenansını belirlerken bu kişileri tanımlayarak idari ilişkileri ortaya koyar ve belgenin kaynağını belirler.

Tablo 1: Belgenin İç Kaynaklı Elemanları

\begin{tabular}{|c|l|}
\hline \multirow{3}{*}{ Protokol } & $\begin{array}{l}\text { antet } \\
\text { başlık } \\
\text { tarih } \\
\text { adres } \\
\text { konu } \\
\text { sayı } \\
\text { kontrol numarası }\end{array}$ \\
\hline \multirow{3}{*}{ Metin } & $\begin{array}{l}\text { giriş } \\
\text { bildirim, tartışma, açıklama } \\
\text { düzen ve tertip } \\
\text { bitiş cümleleri }\end{array}$ \\
\hline Sorumluluk & $\begin{array}{l}\text { onay } \\
\text { (tarih) } \\
\text { selam ve iltifat cümlesi } \\
\text { tasdik } \\
\text { imza } \\
\text { imza sahibi } \\
\text { imza sahibinin unvanı }\end{array}$ \\
\hline
\end{tabular}


Bir belgede tasdik formu, genellikle tek amirin imzasıyla ortaya konulurken, özellikle makam oluru yazıları, kurul kararları, raporlar ve tutanak türü belge örneklerinde olduğu gibi birden fazla imzadan da meydana gelebilir. Bu durumu, bürokratik gelenek kadar özellikle belgenin üretilmesine hukuki dayanak oluşturan mevzuatın şekillendirdiği söylenebilir. Makam olurları başta olmak üzere, komisyon, meclis, kurul gibi toplulukların üretmiş olduğu belgeler, çok imzalı örneklerdir. Bu belgelerdeki imza sahiplerinin yetkili kişiler olduğunun ortaya konulması, aynı şekilde olması gereken imza sayısının bulunup bulunmadığının belirlenmesi, yine diplomatik analizle mümkündür. Bu tasdik biçimleri yanı sıra belgelerin kurumda kalan ikinci nüshalarındaki parafelerin de üretim ve denetimden sorumlu kişileri hiyerarşik bir yapıda gösterdiğini gözden uzak tutmamak gerekir. Buraya kadar açıklanmaya çalışılan iç kaynaklı elemanlar kısaca şunlardan ibarettir (Duranti, 1991, s. 15).

\section{Dış Kaynaklı Elemanlar}

Bir belgenin orijinal formunda, onun boyutu, biçimi, yazı stili, soğuk damga, kurum amblemi ve özel işaretler biçiminde görülen unsurlar, dış kaynaklı elemanları ifade etmektedir. Görsel olarak da tespit edilebilen bu elemanlar, belgelerin fiziksel yönünü nitelediğinden (Duranti, 1991, s. 7), bilgi açısından iç kaynaklı olanlar kadar değeri yokmuş gibi gözükebilir. Fakat diplomatik analizin bütünü düşünüldüğünde yapacağı katkı açıktır. Bu yüzden bir dokümanın kâğıt belge, mikroform veya dijital olduğunun belirtilmesi, hatta bir harita, proje ya da diplomanın ölçülerinin verilmesi orijinalliklerinin ifadesinde oldukça anlamlıdır. Bunlara çizgiler, şablonlar ve tablolar da dahil edilebilir (Turner, 1990, s. 92).

Belgelerin şekil yönünü niteleyen bu boyut ve ölçüler, her ne kadar bilinen klasik kayıt ortamı olan kâğıt belgeler için düşünülse de, elektronik evrak üretiminin her geçen gün artarak devam etmesi, özellikle hukuk alanında kabul edilip bir vesika işlevi görmeye başlamasıyla, artık elektronik evraklar için de aynı ölçülerin geçerli olacağını görmekteyiz, (InterPRASE Project 2005).

Belgelerin yazı biçimi, bir şekil ve tablo gibi dış kaynaklı elemanlardan sayılmıştır. Teorisyenler, önceleri özel ve aile yazışmalarına, idarenin üretmiş olduğu evraklara, ticari yazışmalara ve muhasebe kayıtlarına dokümanın tip, ritim, stil, mürekkep ve yazı biçimini açıklayan metotlar uygulamışlardır (Duranti, 1991, s. 8). Böylece bu metotlar belgenin orijinalliğinin değerlendirilmesinde bir araç olmuştur.

Bir belgenin analizinde önemli araçlardan biri de, belgenin esas metninin dışında verilen çeşitli açıklamalardır. El yazısı, damga veya makine ile 
yazılabilen bu notlar, o evrakla ilgili ek bir açıklama yapmak, yanlış bir bilgiyi düzeltmek veya evrakın havalesini göstermek için yazılır. Örneğin incelenen makam oluru üst yazısında bulunan açıklamalar tipik "havale notu"dur. Notlardan yazının İstanbul Valiliğinden İ Sağlık Müdürlüğüne, buradan da Personel Şube Müdürlüğüne havale edildiğini öğreniyoruz (Bkz. Ek 1).

Tablo 2: Belgenin Dış Kaynaklı Elemanları

\begin{tabular}{|c|c|c|}
\hline \multicolumn{2}{|c|}{ Taşıyıcı ortam } & $\begin{array}{l}\text { Materyal (kâğıt - diğer) } \\
\text { Mesajı ileten semboller (yazı - resim) } \\
\text { Mizanpaj, düzen } \\
\text { Çizgiler, bloklar, şablonlar ve tablolar } \\
\text { Yazı tipi } \\
\text { Yazılış biçimi: el yazısı, daktilo, bilgisayar } \\
\text { Mürekkep }\end{array}$ \\
\hline \multicolumn{2}{|l|}{ Yazı } & $\begin{array}{l}\text { Noktalama işaretleri } \\
\text { Kısaltmalar ve remizler } \\
\text { Yazı karakteri biçimi, büyük - küçük harf } \\
\text { Silinme, değiştirme, düzeltme } \\
\text { Bilgisayar çıkııı ise yazılım adı } \\
\text { Yazılımın sürümü } \\
\text { Yazı karakteri }\end{array}$ \\
\hline \multicolumn{2}{|l|}{ Dil } & $\begin{array}{l}\text { Kullanılan terminoloji } \\
\text { Anlatım } \\
\text { Üslup }\end{array}$ \\
\hline \multicolumn{2}{|c|}{ Mühür ve damgalar } & $\begin{array}{l}\text { Materyal } \\
\text { Biçimi ve büyüklüğü } \\
\text { Baskısı } \\
\text { Yazısı veya işaretleri }\end{array}$ \\
\hline \multirow{3}{*}{$\begin{array}{c}\text { Notlar ve } \\
\text { ilaveler }\end{array}$} & $\begin{array}{l}\text { İşlem } \\
\text { safhasında }\end{array}$ & $\begin{array}{l}\text { Doğruluğunu ispatlayan kayıtlar: } \\
\text { Evrak kayıt numarası } \\
\text { Geliş tarihi } \\
\text { Sayısı }\end{array}$ \\
\hline & $\begin{array}{l}\text { Kullanım } \\
\text { safhasında }\end{array}$ & $\begin{array}{l}\text { Metnin yanındaki işaretler } \\
\text { Havale notları } \\
\text { İşlemin konusu } \\
\text { İşlemi yapacak birim } \\
\text { İşlemin biçimi (ivedi, günlü) }\end{array}$ \\
\hline & $\begin{array}{l}\text { Yönetim } \\
\text { safhasında }\end{array}$ & $\begin{array}{l}\text { Konu numarası } \\
\text { Arşive geliş tarihi }\end{array}$ \\
\hline
\end{tabular}


Havale bilgisi yanı sıra kayıt mührü ve numarası da bir belgenin idari sürecini yansıtması bakımından önemli birer elemandır. Bir belgenin idari açıdan işlemini takip için kullanılabilecek bir alan olan kayıt bilgisi, diplomatik analiz sırasında belgenin ilgiliye ulaştığını ve zamanını belirtir.

Belgelerin doğruluğunun değerlendirilmesinde kullanılan önemli araçlardan biri, imza gibi yetkili tüzel kişiliği ifade eden mühür olup genellikle belgenin onay kısmında yer alır. Mührün, şekle dayalı bir yönü bulunduğundan belgenin fiziksel tarafını nitelediği düşünülerek dış kaynaklı kabul edilmiştir (Duranti, 1991, s. 10). Soğuk damga biçiminde olan veya ıstampa mürekkeple basılan mühür, belgenin güvenirliğini ve yetkili bir idari mekanizma tarafından tasdikini gösterir. Bu bakımdan bir belgenin tasdikinde etkili yollardan biri olan mühür, aynı zamanda belgenin orijinalliğinin bir delilidir. Dolayısıyla mührün bir belgeyi şekil olarak nitelemesine rağmen, özellikle içerdiği bilgiler ve idari işlemdeki işlevi açısından ele alındığında, entelektüel tarafının bulunduğu inkâr edilemez (Duranti, 1991, s. 10).

Görüldüğü gibi dış kaynaklı ve iç kaynaklı elemanlar, bir bütün olarak düşünüldüğü zaman doküman formunu açıklamaktadırlar. Tek başlarına belge formunu ifade etmeleri yeterli değildir. Her iki eleman grubu bir bütün halinde birbirlerini tamamladıklarından, diplomatik analiz yapılırken ikisi birlikte kullanılır.

\section{Diplomatik Analiz}

Önceki kısımda açıklanmaya çalışılan tüm elemanlar, yazışmalar göz önünde bulundurularak tanımlansa da belge türüne göre geliştirilebilir. Bu tanımlamanın öncelikli amacı, idari işlemlerin çeşitli prosedür ve uygulamalarını tek bir belge formu içine koyabilmek ve yürütülen işlem tipleriyle formu oluşturan özelliklerin farklı kombinasyonlarını gösterebilmektir. Çünkü diplomatik metot ile belgenin otantikliği incelenirken, bir yerde belge formunda onun üretildiği fonksiyonu ortaya koyabilecek bir yol belirlenir (Duranti, 1991, s. 17). Böylece diplomatik analiz, başlatılan bir iş ya da uygulamanın belgenin formu kullanılarak ortaya çıkarılmasını sağlar. Bu analiz, idari işlemler sırasında tabii olarak doğan belgenin hukuki ve idari içeriğini anlamayı amaçlamaktadır.

Belge formuna ait özelliklerin bilinmesi, var ise farklı tarafların gösterilmesi, özel diplomatik veya dokümanter analiz işlemiyle mümkündür. Özel diplomatik analiz, bir belgenin özelden genel karakteristiklerine doğru özenle yapılan bir işlemdir. Bir belgenin üretilmeye başlanmasından en son işlemi bitene kadar geçen süreçte sahip olduğu elemanların, onun form yapısından ortaya çıkarılmasıdır. Daha sonra değişmeyip olduğu gibi kalan bu form yapısı, belgenin ait olduğu türüne göre tipini oluşturur. Belge formunda şunlar 
gösterilebilir: Üretilmesine razı olan kişiler, üzerindeki imzaların liyakatleri, genelini kapsayan faaliyetin tipi, faaliyetin ismi, belge türü, prosedür ve belge arasındaki ilişki ve diplomatik karakteri (Storch, 1998, s. 370). İşte tüm bu unsurlar, belgenin iç ve dış kaynaklı elemanlarına gizlenmiş bilgilerdir. İyi bir diplomatik metot ışığında yapılacak dokümanter analiz, belirtilen sorulara cevap bulunmasına imkân verecektir.

Oldukça katı olan diplomatik analizin yapısı, özelden genele sistematik bir gelişmeye odaklanır. Bu uygulama, belgenin bilinen taraflarının incelenmesiyle bilinmeyen kısımları hakkında tespitler yapmayı sağlar. Bu bakımdan diplomatik analizin Tablo 3'de verildiği şekilde bir yol takip ettiği görülür.

Tablo 3: Diplomatik Analiz Süreci

\begin{tabular}{|c|c|}
\hline Dış kaynaklı elemanlar & $\begin{array}{l}\text { Ebat } \\
\text { Yazı } \\
\text { Dil } \\
\text { Mühürler } \\
\text { İşaretler }\end{array}$ \\
\hline İç kaynaklı elemanlar & $\begin{array}{l}\text { Protokol } \\
\text { Metin } \\
\text { Sorumluluk }\end{array}$ \\
\hline Kişiler & $\begin{array}{l}\text { Uygulamanın yetkilisi } \\
\text { Belgenin yazarı } \\
\text { Uygulamanın adresi } \\
\text { Belgenin adresi } \\
\text { İkinci tasdik imzacısı } \\
\text { Deliller }\end{array}$ \\
\hline İmzaların niteliği & İlgili kişilerin idari düzeyi ve yetkisi \\
\hline Uygulama türü & $\begin{array}{l}\text { Basit, mukaveleden doğan, ortaklaşa } \\
\text { Çok kısımlı, sürekli, karmaşık veya prosedürlere bağlı }\end{array}$ \\
\hline Uygulama adı & Satış, yetki, tedarik, görevlendirme, atama. \\
\hline $\begin{array}{l}\text { Belge ile prosedür } \\
\text { arasındaki ilişki }\end{array}$ & $\begin{array}{l}\text { Belgenin ilişkili olduğu genel prosedürler ve } \\
\text { uygulama prosedüründen dokümanın çıkaracağı } \\
\text { özel prosedür }\end{array}$ \\
\hline Belge tipi & $\begin{array}{l}\text { İsmi (mektup, sözleşme, senet, vs.) } \\
\text { Kaynağı (kamu ya da özel) } \\
\text { Fonksiyonu (düzenli, geçici, deneme) } \\
\text { Durumu (orijinal, karalama veya kopya) }\end{array}$ \\
\hline Diplomatik tanımlama & $\begin{array}{l}\text { İçerik (yıl, ay, gün ve yer) } \\
\text { Eylem (kişi, uygulama) } \\
\text { Belge (form ismi, kaynak, fonksiyon, ebat, miktar) }\end{array}$ \\
\hline
\end{tabular}




\section{Sağlık Bakanlığında Üretilen İki Yazışma Üzerinde Uygulama}

Bilinen diplomatik kuralların günümüz belgeleri için geliştirilmiş biçimi olan bu analiz, pek tabii Cumhuriyet dönemi belgeleri için de kullanılabilir. Örnek olarak bu kısımda Sağlık Bakanlığında üretilen bir "makam oluru"nun diplomatik analizi yapılacaktır. Belge, bir personelin yurt dışı izniyle ilgili olarak alınan bakanlık oluruyla alâkalıdır. İki sayfadan ibaret olan yazının ilki bakan adına müsteşarın imzaladığı "makam oluru" (ISM, 2000a), ikincisi ise bu olur evrakının "üst yazısıdır" (ISM, 2000b). Diplomatik analiz, belgenin içeriği ile doğrudan ilgili olmayıp, form özelliklerini ele aldığı için hem makalede hem de belge örneklerinde işleme konu olan kişi / kişilerin ismi verilmemiştir (Bkz. Ek 1 ve Ek 2).

\section{Birinci Belge: ÜST YAZI (Bkz. Ek 1)}

Dış kaynaklı elemanlar

$>$ A4 $(29,7 \times 21 \mathrm{~cm})$ yazı kağıdı.

> Belge, bilgisayar ortamında Microsoft Office Word'de yazılmış normal ölçülerde bir metne sahiptir. Antet ve sayı alanında kalın harfler kullanılmıştır. Yazı karakteri Times olup, punto büyüklüğü 12'dir.

> Yazı, bilgisayar çıktısıdır.

$>$ Dili Türkçe'dir.

- Yazı, iki paragraftan oluşmaktadır.

- Evrak kayıt numarası, imzalar ve Sağlık Müdürlüğünde verilen havale notu elyazısıdır. Valilik havalesi ise ıstampa mürekkepli mühürle basılmış bir nottur.

> İstanbul İ Sağlık Müdürlüğünün kayıt mührü bulunmaktadır.

> Kayıt tarihi: 27 Ağustos 1999.

$>$ Kayıt no: 13838 .

> Yazı, 26 Ağustos 1999 tarihinde İstanbul Valiliğinden İl Sağlık Müdürlüğüne.

> 31.08.1999 tarihinde İ Sağlık Müdür Yrd. tarafından Personel İşleri Şube Müdürlüğüne havale edilmiştir.

$>$ Belgeye herhangi bir konu numarası verilmemiştir.

iç kaynaklı elemanlar

Protokol

> Antet: T.C. SAĞLIK BAKANLIĞı Dış İlişkiler Dairesi Başkanlığı

> Tarih: Istampa mürekkeple basılmış halde; 24 AĞUSTOS 1999 
> SayI: B100DIŞ0000007/ 2086

$>$ Konu: Dr A... K...

$>$ Adres: ISTANBUL VALILiĞi (il Sağlık Müdürlüğüne)

Metin

> Giriș: Amerika Birleşik Devletleri Arkansas Üniversitesi Nöroşirürji Kliniğinde... bilgi ve görgüsünü artırmak amacıyla; ... makam onayı ilişikte sunulmuştur

- Açıklama: Keyfiyetin tebliğ edilmesi,

> Bitiş:... Dairemize gönderilmesini rica ederim

Sorumluluk

> Tasdik eden: Bekir METIN

> Makamı: Bakan adına Daire Bşk.

- Imza: İsim üstüne el yazısıyla atılmış

Kişiler

> Uygulama yetkilisi: Sağlık Bakanlığı Dış İlişkiler Dairesi Başkanlığı

> Belgenin yazarı: Dış Ilişkiler Dairesi Başkanlığı

> Uygulamanın adresi: ISTANBUL VALiLiĞi iı Sağlık Müdürlüğü

> Belgenin adresi: íSTANBUL VALiLiĞi î Sağlık Müdürlüğü

- Yazan: Bekir METiN

İmzanın niteliği

> Dış İlişkiler Dairesi Başkanlığı

Uygulama türü

> Basit işlem

Uygulama adı

> Maaşsız izin

Doküman ile prosedür arasındaki ilişki

> Maaşsız izin onayının muhabere evrakı (üst yazı)

Doküman tipi

$>$ İsmi: Üst yazı

- Kaynağı: Kamu

> Fonksiyonu: İzin işlemleri, düzenli fonksiyon

- Durumu: Orijinal

Diplomatik tanımlama

> içerik: 24 AĞUSTOS 1999, (Ankara, Türkiye)

> İslem: Dr. A... K...'ya yurt dışında maaşsız izin verilmesiyle ilgili

$>$ Belge: 1 adet üst yazı, kamu, orijinal, maaşsız izin 
İkinci Belge: ONAY BELGESi (Bkz. Ek 2)

Dış kaynaklı elemanlar

$>$ A4 $(29.7 \times 21 \mathrm{~cm}$.) yazı kağıdı.

- Belge, bilgisayar ortamında Microsoft Office Word'de yazılmış normal ölçülerde bir metne sahiptir. Antet ve sayı alanında kalın harfler kullanılmıştır. Yazı karakteri Times olup, punto büyüklüğü 12'dir.

$>$ Yazı, bilgisayar çıktısıdır.

- Dili Türkçe'dir.

- Yazı, tek paragraftan oluşmaktadır.

- Evrak kayıt numarası, imzalar ve onay tarihi elle yazıımıştır.

- Kayıt işlemleri üst yazıya yapıldığından bu belgede İ Sağlık Müdürlüğünde yapılan herhangi bir kayıt bulunmamaktadır.

$>$ Belge kopyadır ve tasdik edilmiştir.

- Belgenin sol alt kısmına gelecek şekilde Istampa mürekkeple "ASLI GiBiDiR" mührü vurulmuştur.

> Belge ise, Ülkü IŞıK Sağlık Bakanlığı Dış İlişkiler Dairesi Başkanlığı Dış Eğitim Proje ve Konferanslar Şube Müdürü Ülkü IŞIK tarafından tasdik edilmiştir, Müdürlüğün mührü vurulmuştur.

> Mühürde T.C. kısaltması okunabilmekte ve orta kısımda bulunan ay yıldız görülebilmektedir. Diğer bilgiler silik çıkmıştır.

iç kaynaklı elemanlar

Protokol

- Antet: T.C. SAĞLIK BAKANLIĞI DIŞ ILIŞKKILER DAIRESI BAŞKANLIĞI

> Tarih: ıstampa mürekkeple basılmış halde; 23 AĞUSTOS 1999

> Sayr: B100DIŞ0000007/6619

$>$ Konu: Dr A... K...

- Adres: BAKANLIK MAKAMINA

Metin

> Giriş: Amerika Birleşik Devletleri Arkansas Üniversitesi Nöroşirürji Kliniğinden sağlamış olduğu

> Açıklama: İstanbul Bakırköy Ruh ve Sinir Hastalıkları Hastanesi Beyin ve Sinir Cerrahi Uzmanı Dr A... K...'nun ...

- Bitiş: ... tarihleri arasında maaşsız izinli sayılmasını onaylarınıza arz ederim. 
Sorumluluk

$>$ Teklif eden: Bekir METIN

- Makamı: Daire Başkanı

> Imza: İsim üstüne el yazısıyla atılmış

- Tasdik eden: Doç Dr. Semih YALÇIN

> Makamı: Müsteşar Vekili

$>$ Onay tarihi: 23.08.1999

Kișiler

- Uygulamada yetkili: Sağlık Bakanlığı Dış Ilişkiler Dairesi Başkanlığı

> Dokümanın yazarı: Dış Illişkiler Dairesi Başkanlığı

- Uygulamanın adresi: Bakanlık Makamı

- Dokümanın adresi: Bakanlık Makamı

- Yazar: Bekir METiN, Daire Başkanı

İmzanın niteliği

> Bakanlık Makamı

Uygulama türü

> Makam Oluru

Uygulama adı

- Maaşsız İzin

Doküman ile prosedür arasındaki ilişki

- Maaşsı izin isteğinin makam oluru

Doküman tipi

$>$ ismi: Makam oluru

- Kaynağı: Kamu (Sağlık Bakanlığı)

> Fonksiyonu: İzin işlemleri, düzenli fonksiyon

- Durumu: Kopya

Diplomatik tanımlama

> içerik: 23 AĞUSTOS 1999, (Ankara, Türkiye)

> işlem: Dr. A... K...'ya yurt dışında maaşsız izin verilmesiyle ilgili bakan olurunun alınması

- Belge: 1 adet makam oluru, kamu, kopya, maaşsız izin 


\section{Uygulamanın Değerlendirilmesi}

Diplomatik analiz çalışmalarında iki safha bulunur. Bunlardan ilki diplomatiğin kurallarını uygulayarak, bir belgenin bölümlerini ve buralarda yer alan form elemanlarını ortaya çıkarmaktır. İkinci safha ise bu elemanların sağladığı verilerden hareket ederek belgeyle ilgili bilinmeyen tarafların belirlenmesidir (Turner 1990: 99). Önceki bölümde Bakanlığın ürettiği belgenin form özellikleri diplomatik açıdan belirlenmeye çalışılmıştı.

$\mathrm{Bu}$ bölümde ise belgenin fonksiyonu, formu ve üretildiği kaynağı değerlendirilecektir. İncelenen her iki belge yazışma formunda düzenlendiğinden bir yazışmada bulunması gereken form elemanlarının bu belgelerde de yer aldığı görülmektedir. Böylece bir olur yazısını meydana getiren antet, sayı, adres, metin, teklif eden ve özellikle oluru veren makamı, burada da görmek mümkündür.

Diplomatik analizde esas amaçlardan birinin belge ile fonksiyon ilişkisinin ortaya konulması olduğu daha önce belirtilmişti. Belgeyle ilgili fonksiyonun açıklanmasına, belgenin üretilmesine hukuki gerekçe oluşturan prosedürle başlamak yerinde olacaktır. Her iki belgenin metninde özellikle idari işlemin dayandığı mevzuat olan ve kamu idaresinde görev yapanların özlük haklarını düzenleyen "657 Sayılı Devlet Memurları Kanunu”nun "bilgilerini artırmak için yabancı memleketlere gönderilenlerin hak ve yükümlülükleri"ni düzenleyen 78. maddesine atıf yapılmıştır (657 Sayılı Devlet Memurları Kanunu, 1965). Metin içerisinde yapılan bu atıf, öncelikle fonksiyonun dayandığı temel gerekçenin anlaşılmasına yardımcı olmaktadır. Böylece belgenin üretildiği fonksiyonun bu madde hükmüne göre yürütüldüğünü söylemek mümkündür.

Bu temel gerekçenin ardından yurt dışında maaşsız izinli sayılma uygulamasının belge formunu oluşturan elemanlardaki yansımasını; dolayısıyla elemanların işlemle olan ilişkisini açıklamak daha kolay olacaktır. İlk dikkat çeken eleman, antet olup burada geçen bilgilerden öncelikle yazının kamu idaresine ait bir belge olduğu anlaşılabilir. Antet, diplomatik açıdan belgenin idari ve hukuki sorumluluğunu taşıyan kurumu, aynı zamanda alt birimi ifade ettiğinden yazıyı üreten tüzel kişiliği göstermektedir. Böylece bu elemanı kullanarak belgenin çıktığı kaynağı ve içerik sorumlusunu belirlemek mümkündür. Buna göre işlem sahibi kişi sağlık çalışanı olduğu için Sağlık Bakanlığı, Bakanlığın yurt dışıyla ilgili tüm faaliyetlerinde olduğu gibi personelin yurt dışı eğitim ve kurs işlemlerini yürütmekle de görevli Dış ilişkiler Dairesi Başkanlığı (DiDB) (Sağlıkta 80 yıl, 2000, s.77) gerekli uygulamayı yapmış ve belgeyi üreten tüzel kişi olarak antetteki yerini almıştır. Burada Daire Başkanlığı sorumluluğu taşıyan taraf olsa da "aslı gibidir" onay kısmında yer alan mühürden belge üreticisinin Başkanlık değil, ona bağlı Dış Eğitim Proje ve Konferanslar Şube Müdürlüğü olduğu anlaşılmaktadır. Ancak, belgeye aslı gibidir kaşesi vurup tasdik eden makam kaşesinin ve 
mührünün dışında, bu müdürlüğü, antet ya da herhangi bir form alanında doğrudan verilmiş halde göremiyoruz (Bkz. Ek 2). Oysa, daire başkanlığı içerisinde yurt dışı izin işlemlerini bu birimin yürüttüğü, başkanlığın görevleri arasında belirtilmektedir (DiDB, 2005). Ayrıca, kurumlarda müdürlüklerin uygulamacı, diğer bir deyişle, fonksiyonla ilgili işlemleri yürüten birim; daire başkanlıklarının ise denetim ve onay makamı olduğu gerçeğini göz ardı etmemek gerekir.

Burada antet ile işlemi yapıp aynı zamanda teklifte bulunan yetkili makamın karşılaştırılması, diplomatik analiz için oldukça kullanışlı ipuçları sunacaktır. Üst yazıyı hazırlayan ile makam oluru yazısının teklifini yapan Dış illişkiler Daire Başkanlığıdır. Bu bilgi, sorumluluk alanında imza formu ile birlikte yer alan daire başkanı unvan bilgisinden çıkarılabilir. İmza formunda bulunan makam unvanı ile antette verilmiş olan alt birimin adı aynı tüzel kişiliği adreslemektedir. Başka bir deyişle, belgeler dış ilişkiler daire başkanlığı tarafından imzalanırken, antette de aynı başkanlığın ismi yer almaktadır. Böylece belgenin, idari usul ve ișlem kurallarına uygun olarak üretildiğini söylemek mümkündür. Bu durum aynı zamanda belgenin olması gereken karakteristik yapısı içerisinde öz niteliklere sahip olduğuna işaret ettiğinden, orijinalliğine de delil teşkil etmektedir.

Diğer taraftan antet ve sorumluluk yani imza alanı bilgisi, belgenin çıktığı kaynağı açıkça göstermektedir. Buna göre belge, Bakanlığın hizmetleriyle alâkalı yurt dışı iş ve işlemlerini yürüten Dış ilişkiler Dairesi Başkanlığından çıkmıştır. Dolayısıyla yapılan işlem ile başkanlığın doğrudan fonksiyon ilişkisi bulunmaktadır.

Belgenin üretildiği kaynağı adresleyen diğer bir bilgi alanı harf ve rakamlardan meydana gelen "Sayı:" kısmıdır. Burada geçen harfler, kamu idaresini kapsayan yürütme yani Başbakanlık başta olmak üzere Sağık Bakanlığını ve Dış Ilişkiler Daire Başkanlığını ifade etmektedir (Bkz. Ek 1 ve Ek 2).

İncelenen birinci belge olan üst yazıdan, izinle alâkalı diğer prosedür ve işlemleri görmek mümkündür. Belgenin "ilgi:" alanındaki referanslardan ilk olarak İstanbul Valiliği İ Sağlık Müdürlüğü'nden bir yazı alındığı; ardından Sağlık Bakanlığı Personel Genel Müdürlügü ve Tedavi Hizmetleri Genel Müdürlüğü ile yazışmalar yapııdığı anlaşılmaktadır. Bütün bu yazışmalar, izin işlemiyle ilgili olarak Bakanlıktan olur alınması için gerekli prosedür ve idari işlemlerin yerine getirilmesinde yürütülen faaliyetleri göstermektedir. Aynı zamanda makam oluru yazısı öncesinde işlemin geçirdiği idari süreci yansıtmaktadır. $\mathrm{Bu}$ durum, belgenin idari usuldeki prosedürü tamamlamasının yanı sıra idari kontrolün de sağlandığını göstermektedir. Çünkü Bakanlık, olur vermeden önce işlemi yapan daire başkanlığı aracılığıyla belirtilen birimlerden işlem için herhangi bir engel olup olmadığını sormuştur. Dolayısıyla yapılacak işlemle ilgili tüm karar mekanizmaları 
görüşlerini ortaya koymuş, son karar ise oluru verecek olan makama bırakılmıştır.

Fonksiyon ortaya konurken diplomatik bakımdan dikkat edilmesi gereken bir husus, işlemi yapan yetkilinin durumudur. Öncelikle yurt dışı izin işlemlerinden dış ilişkiler birimi sorumlu olduğundan, idari işlemdeki sorumluluğun da daire başkanına ait olması normal bir durumdur. Fakat yurt dışı izinlerinde karar yetkisi kurumun en üst amirinde bulunduğundan, başkanlık doğrudan izin verememektedir. Bu durumda daire başkanlığının yurt dışı izni verme yetkisi bulunmadığını, sadece işlemi yürütme yetkisinin olduğunu söylemek mümkündür. Zaten Bakan yetki vermeden başkan olur vermeye kalkışmış olsaydı, daire başkanı kendisine verilmeyen bir yetkiyi kullanmış ve geçersiz bir işlem yapmış olurdu ki, bu durum belgenin sahteliğini gündeme getirirdi. Bunun yerine karar yetkisi kurum amirine ait olduğundan işlem en son Sağlık Bakanının oluruna bırakılmıştır. O halde başkanlığın yaptığı işlemin, gerekli prosedür tamamladıktan sonra yazıyı bakanın görüşüne arz etmek olduğunu söylemek mümkündür. Diğer bir ifadeyle, başkanın yaptığı işlem, yurt dışı izninin uygun görülmesi için Bakanlık makamına yapılan bir tekliftir. Kurumun en üst karar mekanizması olan Bakan da yine kendi yetkisini kullanarak uygun görüş belirtmiş, olur kararını vermiştir. Böylece belge üzerindeki sebep sonuç ilişkisinin doğru olarak yürütüldüğünü söylemek mümkündür.

Belge formunda görülmesi gereken bir uygulama da yetki çerçevesinde yapılan işlemlerin sırasıdır. Form unsurlarından anlaşıldığına göre gerekli prosedürün ardından olur yazısı metninin son kısmında daire başkanının "...tarihleri arasında maaşsız izinli sayılmasını onaylarınıza arz ederim" biçimindeki teklifini, Bakan uygun görüp onaylamıştır. Belgede ilk önce teklif ifadesi, ardından teklifin onayını gösteren olur ibaresi yer almaktadır (Bkz. Ek 2). Dolayısıyla belgede yürütülen işlem sırasının prosedüre uygun işlediği anlaşılmaktadır.

Özellikle belgenin güvenirliğini ortaya koymak adına üzerinde durulması gereken bir husus, yetkili imzaların durumudur. Belgede yer alan imzalar, sıcak imza olarak ifade edilen şekliyle, doğrudan yetkili makamların imzasını taşımaktadır. Ancak, olur kısmında bakan yerine onun yetki verdiği müsteşar vekilinin imzasını görüyoruz (Bkz. Ek 2). İmza formu ve verildiği alan her ne kadar olması gereken şekil hususiyetlerine uysa da, makam unvanının kalemle düzeltildiği anlaşılmaktadır. Belge müsteşarlığa vekâlet eden kişi tarafından imzalanmıştır. Buna rağmen belge gerekli idari işlemleri sırasıyla ve prosedürlere uygun tamamladığından, bu unvan düzeltmesi belgenin orijinalliğine bir şüphe getirmemektedir.

Belge imzadan çıktıktan sonra oluşan idari prosedür ise şu şekilde gelişmiştir. Yazıların tarihinden ve olması gereken idari işlem sırasından çıkarılabilecek sonuca göre öncelikle olur yazısı düzenlenmiş, ardından üst 
yazı hazırlanmıştır. Fonksiyonun esas belgesi olan olur yazısı üst yazının eki durumundadır. Eke daha sonraki günün tarihi verilmiştir. Bakanlıktan gerekli kayıt numarasını alan evrak, kayıt ve havale işlemleri sırasında verilen tarihlere göre önce İstanbul Valiliğine gelmiş; ilgili vali yardımcısının havalesiyle İ Sağlık Müdürlüğüne, oradan da personel şubesine gönderilmiştir (Bkz. Ek 1). Bu işlemlerden, olması gereken idari bürokratik sürecin normal seyrinde sıra atlamaksızın işlediği açıkça görülmektedir.

Belge formunu meydana getiren unsurlar ve bunların değerlendirilmesi, doğru bir diplomatik analiz için yeterli gibi gözükse de belgeyi üreten kurumun idari ve bürokratik ilişkilerini belirleyen mevzuatın göz önünde bulundurulması gerektiği anlaşılmaktadır. Çünkü idari basamaklardaki sürece bakıldığında, işlemle doğrudan ilgisi olmayan ara birimlerin bulunduğu düşünülebilir. Örneğin bu yazıda İstanbul Valiliği, belgenin üretim sürecinde bir işlem adımını teşkil etmektedir. Oysa fonksiyonun bütünü göz önüne alındığında, Sağlık Bakanlığı ile Valilik ayrı kurumlar gibi değerlendirilip, sağlık personelinin yurt dışı izin işlemleriyle Valiliğin nasıl bir ilişkisi bulunabilir. Böyle olunca dikkatle ele alınması gereken husus, bu idari ilişkiyi zorunlu kılan sebeplerin olup olmadığıdır. Bu konuya ilk ışık tutacak olan 5442 Sayılı II İdaresi Kanunudur (1949). Bu kanunun 4. maddesine göre valilikler illerde tüm bakanlıkların temsilcisidir; aynı zamanda en yetkili mülki amir olmaları dolayısıyla î Sağlık Müdürlüğü gibi bakanlıkların taşra teşkilatlarının da amiri durumundadırlar. Böylece İstanbul Valiliği, idari olarak III Sağlık Müdürlüğü ile Sağlık Bakanlığı arasında bulunmaktadır. Dolayısıyla belge, idari usul bakımından bakanlıktan valiliğe, valilikten de müdürlüğe gönderilmektedir. Bu durumda, belge arşivlik malzeme olduğunda hem provenans, hem de orijinal düzen değerlendirilirken bu organik yapının nasıl oluştuğu sorusuna cevap bulunabilir.

\section{Sonuç}

Bu yazıda özel diplomatik metodun güncel belgeler üzerinde uygulanmasıyla ilgili bir çalışma ortaya konulmuştur. Sağlık Bakanlığı faaliyetleri kapsamında bir personelin yurt dışı izniyle ilgili üretilen iki belgenin form özellikleri değerlendirilip, diplomatik analizi yapıımıştır.

Arşivlik malzeme olmuş belgeler üzerinde denenen metotların, pek tabii günümüz belgeleri için de kullanılabileceği görülmüştür. Çalışmada ulaşılan en önemli sonuçlardan bir tanesi, diplomatik metodun Cumhuriyet dönemi belgeleri üzerinde uygulanabileceğidir. Bu düşünce, güncel iki belgeyle yapılan uygulamada aydınlatılmaya çalışıımıştır. Ancak, görülen o ki arşivcilerin özel diplomatiği her belge üzerinde doğrudan kullanmaya kalkmaları, onların kafa karışıkığına sebep olabileceği gibi gereksiz birçok ayrıntı 
içerisinde boğulmaları sonucunu doğurabilir. Bu yüzden daha önce de belirtildiği gibi tek belge üzerinde ayrıntılı bir tahlil yerine, belge türleri veya serilerle alâkalı diplomatik analiz yapılması daha uygun olacaktır.

Belgelerin üretildiği kaynağın belirlenebilmesi için belge formunu meydana getiren unsurların genel diplomatikten daha çok özel diplomatik metotlarla ele alınması gerektiği anlaşılmıştır. Çünkü belge formunda yer alan elemanlar, belgenin doğuşuyla birlikte iletim, kullanım ve arşivlenmesi sürecini açıkladığı gibi, aynı zamanda sorumluların ve yetkili organların belirlenmesine imkân vermektedir. Bu tespitin, özel diplomatik analizle mümkün olduğu görülmüştür. Bu yüzden özel diplomatiğe ait uygulamalar, kaçınılmaz olarak arşivcileri meşgul etmeye devam edecektir.

Arşivci, bir belge yerine dosya ve onun bulunduğu serinin tanımlanmasıyla ilgili tahlil yapmak istediği zaman ise özel diplomatiğin yeterli olmadığını görecektir. Bu durumda genel diplomatik metodu kullanması gerekecektir.

Diplomatiğin esas çıkış kaynağı, belgelerin form özellikleri kullanılarak güvenilirliğinin belirlenmesi olduğundan, bu anlayış, doğal olarak yakın dönemde üretilmiş başka belge türleri için de düşünülmelidir. Çünkü güncel bir belgeyi meydana getiren form elemanları benzer hususiyetler göstermektedir. Bu yüzden diğer türlere ait belge profili, bir analiz metodu olarak ortaya konan diplomatik çerçeveye uymaktadır. Makam oluru örneğinde olduğu gibi "rapordan" "diplomaya", "iş yeri ruhsatından", "sözleşmeye" kadar başka belge türlerinin de diplomatik analizi yapılabilir.

Günümüz belgelerinin tipolojileri ve form özelliklerinin entelektüel analizi konusunda yürütülen projeler ve özellikle Duranti'nin belirtilen çalışmaları, diplomatiğin bu dönemde ulaştığı noktayı bizlere göstermektedir. Öyle anlaşılıyor ki, önceki dönemlere ait belgelerin orijinalliklerinin tespiti için geliştirilen diplomatik, güncel belgelerin analizinde kullanıldığı gibi elektronik dokümanlara da uygulanabilir. Bununla birlikte elektronik belgeler, üretilmeleri ve iletilmelerindeki farklı ortam ve koşullardan dolayı orijinalliklerinin tespitinde bir kağıt evraka göre daha fazla güçlük çıkaracaktır.

\section{Kaynakça}

5442 Sayılı İ İdaresi Kanunu (1949). 13 Mayıs 2005 tarihinde http://proje.basbakanlik.gov.tr/mevzuat $/$ metinx.asp? mevzuatkod= 1.3.5442\&sourceXmISearch=il\%20idaresi\%20kanunu adresinden erişildi.

657 Sayılı Devlet Memurları Kanunu (1965). 12 Temmuz 2005 tarihinde http://personel.saglik.gov.tr/mevzuat/657.htm adresinden erişildi. 
Çiçek, N. (2004). Belgelerin karakteristik yapısını oluşturan elemanların fonksiyonla ilişkisi: Güncel belgeler üzerine bir inceleme. B. K. Ataman, M. Yalvaç (Yay. Haz.), Aysel Yontar Armağanı içinde (ss.133-152), İstanbul: Türk Kütüphaneciler Derneği İstanbul Şubesi.

Dış illişkiler Daire Başkanlığı (2005). Sağlık Bakanlığı Dış illişkiler Daire Başkanlığının görevleri. 12 Temmuz 2005 tarihinde http://www.saglik.gov.tr/sb/default.asp?Sayfa=birimler\&sinifi=gorevler\& cid $=12 \&$ sid=92 adresinden erişildi.

Duranti, L. (1989). Diplomatics: New Uses for an Old Science (Part I). Archivaria, 28 (Summer), 7-27.

Duranti, L. (1990). Diplomatics: New Uses for an Old Science (Part III). Archivaria, 30 (Summer), 4-20.

Duranti, L. (1990-91). Diplomatics: New Uses for an Old Science (Part IV). Archivaria, 31 (Winter), 10-25.

Duranti, L. (1991). Diplomatics: New Uses for an Old Science (Part V). Archivaria, 32 (Summer), 6-24.

Duranti, L. (1991-92). Diplomatics: New Uses for an Old Science (Part VI). Archivaria, 33 (Winter), 6-24.

Duranti, L. (1998). Diplomatics: New Uses for an Old Science. Lanham: the Society of American Archivists and Association of Canadian Archivists.

Duranti. L. (1989-90). Diplomatics: New Uses for an Old Science (Part II). Archivaria, 29 (Winter), 4-17.

InterPRASE Project. (2005). The International Research on Permanent Authentic Records in Electronic Systems, 27 Nisan 2005 tarihinde http://www.interpares.org. adresinden erişildi.

İstanbul Büyük Şehir Belediyesi. (1997). Beykoz Çevresinin Jeoloji ve Jeofizik Açısından Yerleşime Uygunluk Değerlendirmesi Raporu, Rapor No: A-17, Haz. Planlama ve İmar Dairesi Başkanlığı, Şehir Planlama Müdürlügü, İstanbul: Belediye, (yayınlanmamış rapor / belge [y.r. / b.]).

İstanbul İ Sağlık Müdürlüğü (1999). Müdürlüğün, 09.07.1999 tarih ve A.P.K104BiSM434000 / 356 Sayılı Arşiv Çalışması İzin Yazısı. İstanbul: Marmara Üniversitesi Fen-Edebiyat Fakültesi Personel İşleri Bürosu.

İstanbul İ Sağlık Müdürlüğü (2000a). Sağlık Bakanlığı, Dış İlişkiler Dairesi Başkanlığının 23.08.1999 tarih ve B100DIŞ0000007 / 6619 sayılı Makam Oluru. İstanbul î Sağlık Müdürlüğü Personel İşleri Şube Şefliği.

İstanbul ilı Sağlık Müdürlüğü. (2000b). Sağlık Bakanlığı, Dış İlişkiler Dairesi Başkanlığının 24.08.1999 tarih ve B100DIŞ0000007 / 2086 sayılı yazısı. İstanbul î Sağlık Müdürlüğü Personel İşleri Şube Şefliği. 
Kandur, H. ve İcimsoy, O. (2002). Iş Yazıları ve Dosyalama Teknikleri. Ankara: Milli Eğitim Bakanlığı.

Öztek, Z. (1999). Sağlık Ocağı Işslevi ve Yönetimi. 7.bs. Ankara: Sağlık Bakanlığı.

Sağlıkta 80 Yıl: 2 Mayıs 1920-2000, (2000). Ankara: Sağlık Bakanlığı.

Sigmond, P. J. (1991-92) Form, function and archival value, Archivaria, 33 (Winter), 141-47.

Skemer, D. C. (1989). Diplomatics and archives. American Archivist, 52 (Summer), 376-382.

Storch, S. E. (1998). Diplomatics: Modern archival method or medieval T.C. Başbakanlık artifac. American Archivist, 61 (fall), 365-378.

T.C. Başbakanlık (2005). Resmi Yazışmalarda Uygulanacak Esas ve Usuller Hakkında Yönetmelik. 10 Mayıs 2005 tarihinde http://www.basbakanlik. gov.tr/sourcedesign/TURKasp?cont=\&pid=\&web_id=basbakanlik\&sayfa _id $=$ adresinden erişildi.

Turner, J. (1990). Experimenting with new tools: Special diplomatics and the study of authority in the United Church of Canada. Archivaria, 30 (Summer), 91-103. 


\section{Ek 1: Sağlık Bakanlığı Makam Oluru Evrakının Üst Yazısı}

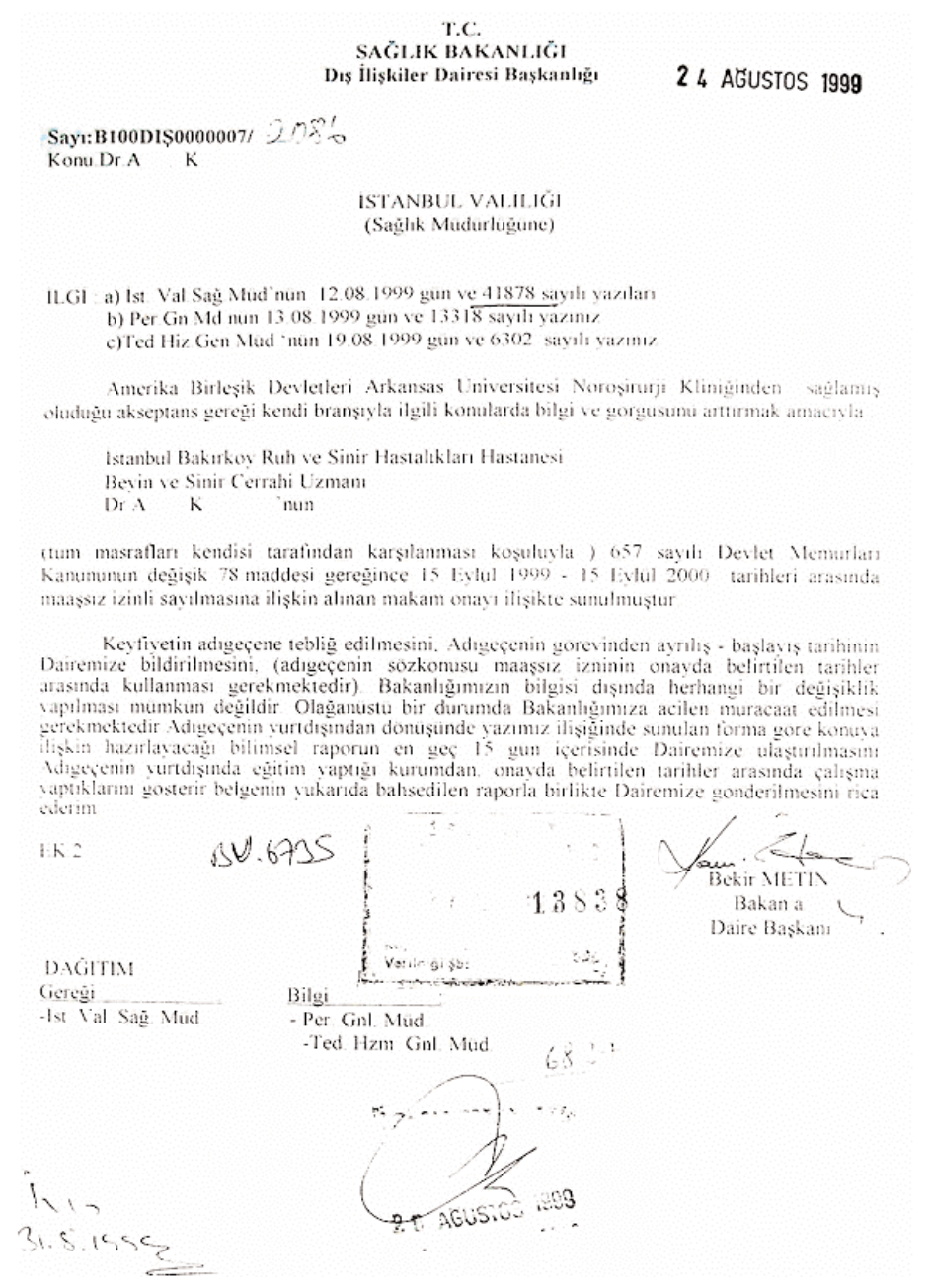




\title{
Ek 2: Sağlık Bakanlığı Makam Oluru Evrakı
}

\author{
T.C. \\ SAG̈IIK BAKAS AIC̈I \\ DIS ILISTKILER DAIRESI BASKANLIĞ \\ Sayı: B100DISs0000007/ bel 4 \\ Konu.Dr.A K \\ 23 AǴUSiOS 1999 \\ BBAKANEIK MAKAMINA

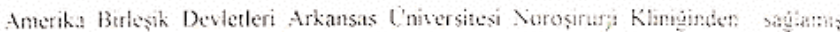 \\ ofudugu akseptans gereğ kendi branşyla ilgili koneiarda bilgi ve gorgusunu arthrmak amacr lat \\ Istantuil Bakthwy Ruh ve Sinir liastaikhan Hastmesi \\ Bum we Sath lemain L zmant \\ Di $+k$ nem

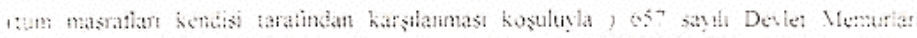

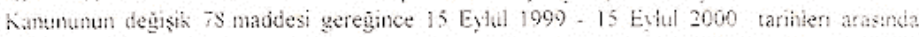 \\ maassız izinli saythmastm onaylarma arz ederim

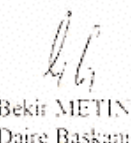

ASLL GIBjRIR.

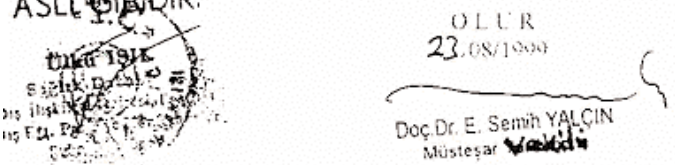

